\title{
Implementation of a GNSS meteorological model to the estimation of the Haines Index
}

\author{
Laura I. Fernández ${ }^{1,2^{*}}$, Juan M. Aragón Paz ${ }^{1,2}$, Amalia M. Meza ${ }^{1,2}$ and Luciano P. O. Mendoza ${ }^{1,2}$
}

\begin{abstract}
Background: The objective of this study was to look for a replacement to the radiosonde measurements that are necessary for the construction of an index of potential wildfire severity (i.e., Haines Index, HI) in areas of South America that have had few to no radiosonde launches. To this end, we tested the application of GPT2w, an empirical model originally developed for Global Navigation Satellite System (GNSS) meteorology. By using the GPT2w model, and starting from measured surface meteorological data (air pressure, temperature, and relative humidity), estimators of air temperature and dew-point air temperature at different pressure levels were generated. The selected testing area was a region of South America that included most of the Río de la Plata drainage basin, along with two hazardous areas: Sierras de Córdoba in Argentina and Serra da Canastra in Brazil. This region was chosen due to the availability of the radiosonde launches required for comparison during 2016.

Results: To characterize the regional performance of HI, we used data from the European Centre for Medium-Range Weather Forecast's (ECMWF) reanalysis model (ERA Interim; Dee et al., Quarterly Journal of the Royal Meteorological Society 137: 553-597, 2011) for the period 2000 to 2016. A statistical analysis of the differences between the simulated HI from GPT2W (HI_GPT2W) and the HI values derived from radiosonde measurements (HI_R) was performed. The results showed that HI_GPT2W reproduced HI_R values about $50 \%$ of the time, most accurately for lowseverity $\mathrm{HI}$ values (2 to 3, on a scale of 2 to 6). In general, HI_GPT2W exhibited an underestimation of HI that increased as the index value increased. We analyzed how this underestimation affected the different $\mathrm{HI}$ variants calculated. To this end, we recall that each $\mathrm{HI}$ variant results from the sum of the stability and moisture terms. The stability term resulted from the temperature difference at different pressure levels while the moisture term is represented by the dew-point depression. Thus, the pressure level limits in the stability term define the $\mathrm{HI}$ variant. In this study, we used the Low-variant $\mathrm{HI}$ (950 and $850 \mathrm{hPa}$ ) and the Mid-variant $\mathrm{HI}(850$ and $700 \mathrm{hPa}$ ). If we analyze this underestimation according to the $\mathrm{HI}$ variants, the moisture term is responsible for the Low variant underestimation and the stability term is responsible for the Mid variant.

Conclusion: The simple application of GPT2w to extrapolate the vertical values of temperature and its dew-point depression is not enough to reproduce the Haines Index as it was measured from radiosonde measurements. Nevertheless, an improved application of GPT2w and the extrapolated saturation water vapor pressure by using the Integrated Water Vapor from Global Navigation Satellite System (GNSS-IWV) values could improve the results.
\end{abstract}

Keywords: GNSS meteorology, GPT2w model, Haines Index, South America

\footnotetext{
* Correspondence: lauraf@fcaglp.unlp.edu.ar

'Laboratorio MAGGIA, Facultad de Ciencias Astronómicas y Geofísicas,

Universidad Nacional de La Plata, Paseo del Bosque s/n, FWA, B1900, La

Plata, Buenos Aires, Argentina

${ }^{2}$ CONICET, Godoy Cruz 2290, Piso 9 (C1425FQB), Buenos Aires, Argentina
} 


\section{Resumen}

Antecedentes: La idea principal de este trabajo es buscar un reemplazo a las mediciones de radiosondas que son necesarias para la construcción de un índice de severidad potencial de incendios forestales (Índice de Haines, HI) en áreas de América del Sur con escasos lanzamientos de radiosondas. Con este fin probamos la aplicación de un modelo empírico (GPT2w) originalmente desarrollado para la Meteorología Global Navigation Satellite System (GNSS). Se generaron estimadores de la temperatura y la temperatura del punto de rocío en diferentes niveles de presión usando el modelo GPT2w y datos meteorológicos medidos en superficie (presión atmosférica, temperatura y humedad relativa). El área de prueba seleccionada comprende una región de Sudamérica que incluye la mayor parte de la cuenca del Río de La Plata junto con dos áreas peligrosas en relación a fuegos de vegetación: las Sierras de Córdoba en Argentina y la Serra da Canastra en Brasil. Esta región fue elegida gracias a la disponibilidad de datos de radiosondas necesarios para la comparación durante el año 2016.

Resultados: Para caracterizar el comportamiento regional del HI, usamos los datos del modelo de re-análisis ERA Interim generados por el European Centre for Medium-Range Weather Forecast (ECMWF) durante el período 2000 -2016. Luego realizamos un análisis estadístico de las diferencias entre los valores de HI simulados con el uso de GPT2w (HI_GPT2W) y los valores de HI calculados desde las mediciones con radiosondas (HI_R). Los resultados mostraron que el HI_GPT2W reprodujo los valores de HI_R casi el 50\% de las veces, siendo más preciso para los valores de HI que indican baja severidad (2-3). En general, el HI_GPT2W muestra una subestimación del HI que se incrementa a medida que el índice del valor crece, especialmente para la variante Baja. Además, el término de humedad es el causante las subestimación de los valores de la variante Baja del HI mientras que el término de estabilidad es el responsable de la falta de coincidencia para los valores de la variante Media del HI.

Conclusiones: La aplicación del GPT2w para extrapolar los valores verticales de temperatura y temperatura del punto de rocío no es suficiente para reproducir el HI calculado desde mediciones con radiosondas. Sin embargo, una aplicación mejorada del GPT2w, usando valores de vapor de agua en saturación extrapolados desde el vapor de agua integrado GNSS (GNSS-IMV), podría mejorar los resultados.

\section{Background}

Haines (1988) first published an empirical index called Lower Atmospheric Severity Index (LASI) to detect the potential for a plume-dominated fire to become large or erratic (Potter et al. 2008; Lu et al. 2011). LASI is now referred to as the Haines Index (HI), and is a useful tool to manage existing fires when surface winds do not dominate fire behavior (Haines 1988). Today, HI is widely used in wildfire forecasting and monitoring in the United States (Winkler et al. 2007, Potter et al. 2008, Lu et al. 2011), although Winkler et al. (2007) also reports its usage by the Servicio Meteorológico Nacional of Argentina.

Moreover, a number of studies have investigated $\mathrm{HI}$ over the recent past in various parts of the world (e.g., Mills and McCaw 2010; Tatli and Türkes 2014). Mills and McCaw (2010) identified that the original HI was too often at severity level 5 or 6 over large areas in Australia because $\mathrm{HI}$ was developed for conditions in the northwest United States; it was not configured to identify the most extreme conditions in Australia. The two continents have different temperature lapse rates and humidity climatology. Consequently, Mills and McCaw (2010)) developed an alternative extended version of $\mathrm{HI}$ named the Continuous Haines Index (C-Haines). The C-Haines Index converts the discrete inputs to the traditional $\mathrm{HI}$ into linear functions of the temperature lapse rate and dew-point depression, thereby eliminating abrupt transitions between categories and differentiating better between elevated values of the index.

Neither HI nor C-Haines have any direct physical relationship to fire activity or behavior. The strength of both indices may be that they encapsulate a wider range of physical processes that may enhance fire activity (Mills and McCaw 2010). It is difficult to distinguish which physical processes these are; hence, HI forecasts should be used as alerts rather than as phenomenological explanation of the physics behind the fire activity (Mills and McCaw 2010).

Tatli and Türkes (2014) studied the climatic pattern of HI for the period 1980 to 2010 by using the hourly data from the National Centers for Environmental Prediction/National Center for Atmospheric Research in several countries on the Mediterranean Sea. They computed HI values at 12:00 GMT, despite the fact that temperature and atmospheric instability can be at their maximum at this time, creating possible inversions in air temperature at the Earth's surface (Enz et al. 2017). The authors also applied the Köppen-Geiger climate classification and found that the highest-level risks were in $\mathrm{B}$ 
type regions (desert areas of the Sahara and Libya, and semi-arid steppe of the Middle East), and moderate-level risks were at the mid-latitude warm, temperate, $\mathrm{C}$ type regions (Greece, Italy, Turkey, Syria, Lebanon, Cyprus, Macedonia, Albania, Serbia, Slovenia, France, Portugal, Spain, Morocco, and Tunisia) (Tatli and Türkes 2014).

The information provided to fire managers by HI can be used to estimate the danger of a given fire event, allowing them to apply suitable fire-fighting strategies. To that end, climatological characteristics of $\mathrm{HI}$ in a given region are needed to estimate the likelihood of having high index values (Winkler et al. 2007), along with an additional analysis showing temporal persistency and frequency of dangerous values in the area.

This study had two main objectives. The first was to characterize the climatological behavior of $\mathrm{HI}$ in the selected region of South America for the purpose of detecting areas of high fire hazard. Because HI was originally designated to fulfill the atmospheric conditions of different areas in the United States, its application to another region of the American continent should be analyzed due to different temperature lapse rates and humidity conditions. The study region was a portion of South America that had at least 17 radiosonde stations operating during 2016. The second objective was to test the application of a model originally designed for GNSS (Global Navigation Satellite Systems) meteorology, the Global Pressure and Temperature 2 wet model (GPT2w; Böhm et al. 2015), to estimate HI in the region. Specifically, GPT2w values were used as a substitution of the radiosonde values of temperature and dew-point temperature at different pressure levels. Then, values computed from measured radio-sounding data (i.e., $\left.H I \_R\right)$ were compared to the respective HI estimation from the GPT2w model.

\section{Methods}

\section{Characterization of the Haines Index in the region}

$\mathrm{HI}$ numerically rates the potential of extreme fire behavior or sudden fire growth by evaluating atmospheric stability and moisture content (Simpson et al. 2014). Thus, $\mathrm{HI}$ is the sum of two components or terms. The stability component is the temperature difference between two fixed lower tropospheric pressure levels. It measures the potential for atmospheric mixing (Winkler et al. 2007). The stability term can have values 1,2 , or 3 , with higher values indicating greater instability. The moisture component is the dew-point depression at a fixed pressure level (Winkler et al. 2007; Lu et al. 2011) and can have values 1,2 , or 3 , with higher values indicating drier air. The pressure levels used depends on the variants of the index. In fact, Haines originally created three variations of the index (Low-variant HI, LHI; Mid-variant HI, MHI: and High-variant HI, HHI) by dividing the US territory into three regions according to surface elevations and climatological divisions (Winkler et al. 2007). Thus, the index is an integer from 2 to 6 , where 6 means highest potential danger for a large wildland fire (see Table 1).

Because the climate of a region plays an important role in determining wildfire risk, a regional characterization of $\mathrm{HI}$ was performed in the selected area to describe expected behavior and to thus identify its spatial and temporal resolution. The region of interest extends from $15^{\circ} \mathrm{S}$ to $35^{\circ} \mathrm{S}$ in latitude and from $35^{\circ} \mathrm{W}$ to $65^{\circ} \mathrm{W}$ in longitude and covers most of the Río de La Plata drainage basin in South America (Caffera and Berbery 2006).

From Fig. 1 and Table 2, one can see that several climate types following the Köeppen-Geiger climate classification (Peel et al. 2007) are represented in this extended area. Effectively, three dominant climate types

Table 1 Computation details of the Haines Index (HI). $\Delta T_{\mathrm{A}}$ and $\Delta T_{\mathrm{B}}$ indicate the temperature difference of the stability and moisture term, respectively. Three variants are defined depending on elevation: Low-variant Haines Index (LHI), Mid-variant Haines Index $(\mathrm{MHI})$, and High-variant Haines Index $(\mathrm{HHI}) . T$ is the air temperature and TD is the dew-point temperature at the atmospheric pressure level indicated at the respective subscript. $H I=\Delta T_{\mathrm{A}}+\Delta T_{\mathrm{B}}$ for all variants. The resulting values are classified as: 2 to 3 (very low), 4 (low), 5 (moderate), and 6 (high)

\begin{tabular}{|c|c|c|c|c|}
\hline \multirow[t]{2}{*}{ Variants } & \multicolumn{2}{|c|}{ Stability } & \multicolumn{2}{|c|}{ Moisture } \\
\hline & Condition & Term value & Condition & Term value \\
\hline $\mathrm{LHI}$ & $\Delta T_{\mathrm{A}}<4{ }^{\circ} \mathrm{C}$ & 1 & $\Delta T_{B}<6{ }^{\circ} \mathrm{C}$ & 1 \\
\hline$\Delta T_{\mathrm{A}}=T_{950 \mathrm{hPa}}-T_{850 \mathrm{hPa}}$ & $4^{\circ} \mathrm{C} \ll \Delta T_{\mathrm{A}} \ll 77^{\circ} \mathrm{C}$ & 2 & $6{ }^{\circ} \mathrm{C} \ll \Delta T_{B} \ll 9^{\circ} \mathrm{C}$ & 2 \\
\hline$\Delta T_{\mathrm{B}}=T_{850 \mathrm{hPa}}-T D_{850 \mathrm{hPa}}$ & $\Delta T_{A} \gg 8{ }^{\circ} \mathrm{C}$ & 3 & $\Delta T_{\mathrm{B}} \gg 10^{\circ} \mathrm{C}$ & 3 \\
\hline $\mathrm{MHI}$ & $\Delta T_{\mathrm{A}}<6^{\circ} \mathrm{C}$ & 1 & $\Delta T_{B}<6^{\circ} \mathrm{C}$ & 1 \\
\hline$\Delta T_{\mathrm{A}}=T_{850 \mathrm{hPa}}-T_{700 \mathrm{hPa}}$ & $6{ }^{\circ} \mathrm{C} \ll \Delta T_{\mathrm{A}} \ll 10^{\circ} \mathrm{C}$ & 2 & $6{ }^{\circ} \mathrm{C} \ll \Delta T_{\mathrm{B}} \ll 12{ }^{\circ} \mathrm{C}$ & 2 \\
\hline$\Delta T_{\mathrm{B}}=T_{850 \mathrm{hPa}}-T D_{850 \mathrm{hPa}}$ & $\Delta T_{\mathrm{A}} \gg 11^{\circ} \mathrm{C}$ & 3 & $\Delta T_{\mathrm{B}} \gg 13^{\circ} \mathrm{C}$ & 3 \\
\hline $\mathrm{HHI}$ & $\Delta T_{\mathrm{A}}<18^{\circ} \mathrm{C}$ & 1 & $\Delta T_{B}<15^{\circ} \mathrm{C}$ & 1 \\
\hline$\Delta T_{\mathrm{A}}=T_{700 \mathrm{hPa}}-T_{500 \mathrm{hPa}}$ & $18{ }^{\circ} \mathrm{C} \ll \Delta T_{\mathrm{A}} \ll 21^{\circ} \mathrm{C}$ & 2 & $15^{\circ} \mathrm{C} \ll \Delta T_{\mathrm{B}} \ll 20^{\circ} \mathrm{C}$ & 2 \\
\hline$\Delta T_{\mathrm{B}}=T_{700 \mathrm{hPa}}-T D_{700 \mathrm{hPa}}$ & $\Delta T_{\mathrm{A}} \gg 22^{\circ} \mathrm{C}$ & 3 & $\Delta T_{B} \gg 21^{\circ} \mathrm{C}$ & 3 \\
\hline
\end{tabular}




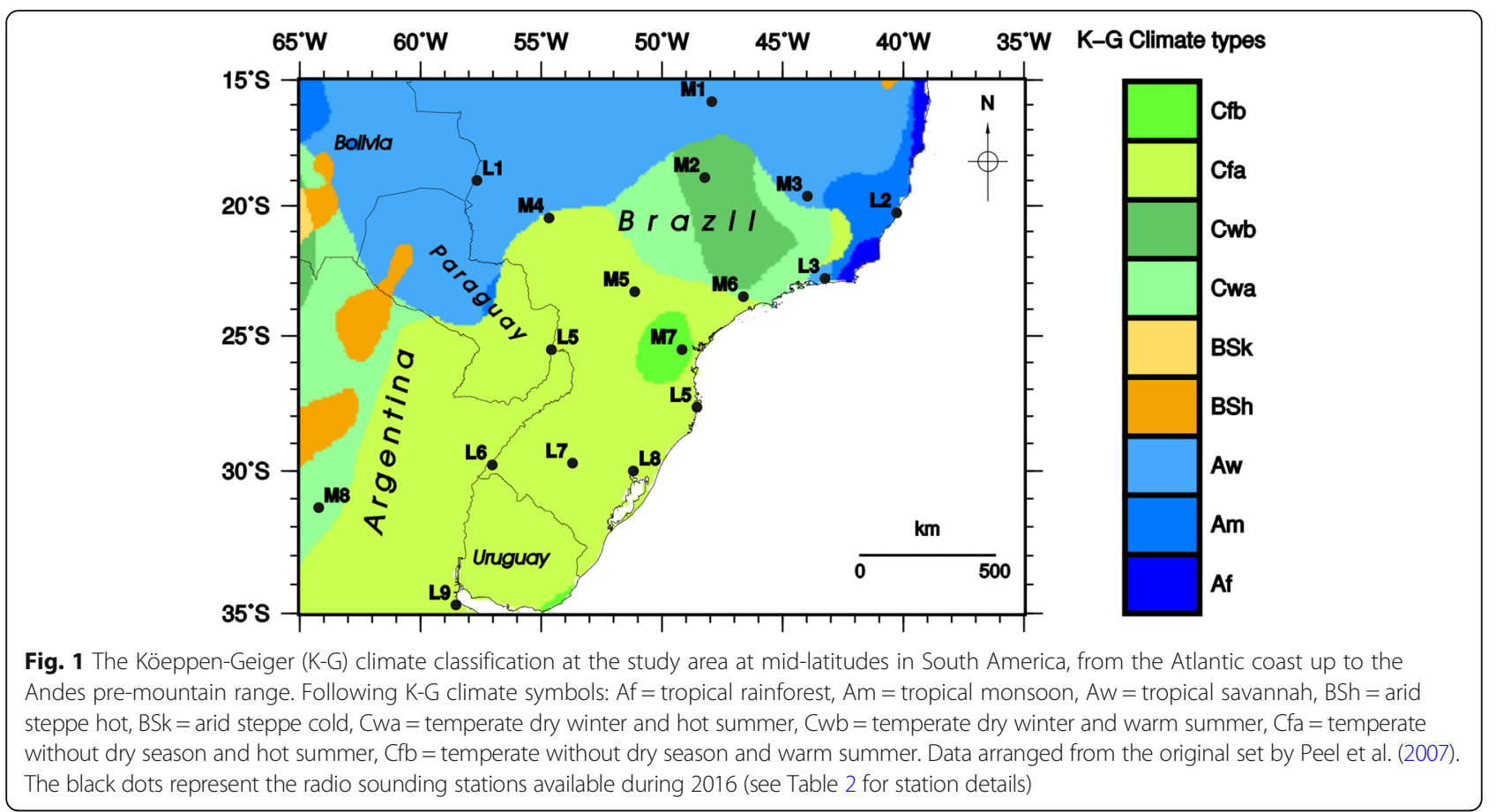

Table 2 Location of available radiosonde launching places during 2016 at mid-latitudes in South America, from the Atlantic coast up to the Andes pre-mountain range. $L$ indicates Low-variant Haines Index (LHI) and M is Mid-variant Haines Index (MHI); (see Fig. 1 for IDs). Each location is identified by city and country name $(\mathrm{Br}=\mathrm{Brazil}, \mathrm{Ar}=$ Argentina). The number radio soundings at each station is also provided

\begin{tabular}{llllcc}
\hline ID & Location & $\begin{array}{l}\text { Latitude } \\
\text { (degree) }\end{array}$ & $\begin{array}{l}\text { Longitude } \\
\text { (degree) }\end{array}$ & $\begin{array}{c}\text { Elevation } \\
(\mathrm{m})\end{array}$ & $\begin{array}{l}\text { Soundings } \\
(n)\end{array}$ \\
\hline L1 & Corumba (Br) & $19.00 \mathrm{~S}$ & $57.66 \mathrm{~W}$ & 141 & 208 \\
L2 & Vitoria (Br) & $20.27 \mathrm{~S}$ & $40.28 \mathrm{~W}$ & 4 & 137 \\
L3 & Galeao (Br) & $22.49 \mathrm{~S}$ & $43.15 \mathrm{~W}$ & 6 & 288 \\
L4 & Foz do lguassu (Br) & $25.52 \mathrm{~S}$ & $54.58 \mathrm{~W}$ & 180 & 261 \\
L5 & Florianopolis (Br) & $27.66 \mathrm{~S}$ & $48.55 \mathrm{~W}$ & 5 & 268 \\
L6 & Uruguaiana (Br) & $29.78 \mathrm{~S}$ & $57.03 \mathrm{~W}$ & 74 & 127 \\
L7 & Santa Maria (Br) & $29.72 \mathrm{~S}$ & $53.70 \mathrm{~W}$ & 85 & 247 \\
L8 & Porto Alegre (Br) & $30.00 \mathrm{~S}$ & $51.18 \mathrm{~W}$ & 3 & 186 \\
L9 & Ezeiza (Ar) & $34.49 \mathrm{~S}$ & $58.32 \mathrm{~W}$ & 20 & 325 \\
M1 & Brasilia (Br) & $15.87 \mathrm{~S}$ & $47.93 \mathrm{~W}$ & 1061 & 260 \\
M2 & Uberlandia (Br) & $18.88 \mathrm{~S}$ & $48.22 \mathrm{~W}$ & 943 & 131 \\
M3 & Confins (Br) & $19.62 \mathrm{~S}$ & $43.97 \mathrm{~W}$ & 827 & 253 \\
M4 & Campo $\mathrm{Grande}(\mathrm{Br})$ & $20.28 \mathrm{~S}$ & $54.40 \mathrm{~W}$ & 567 & 266 \\
M5 & Londrina (Br) & $23.33 \mathrm{~S}$ & $51.13 \mathrm{~W}$ & 569 & 121 \\
M6 & Marte Civ/Mil (Br) & $23.31 \mathrm{~S}$ & $46.38 \mathrm{~W}$ & 722 & 362 \\
M7 & Curitiba (Br) & $25.52 \mathrm{~S}$ & $49.17 \mathrm{~W}$ & 908 & 168 \\
M8 & Cordoba (Ar) & $31.19 \mathrm{~S}$ & $64.13 \mathrm{~W}$ & 474 & 277 \\
\hline
\end{tabular}

of South America are present in this region: tropical, temperate, and some arid areas. The selected area includes several types of vegetation from forest to grasslands. However, the distribution of the fuel beds and their fire potential (e.g., Pettinari et al. 2013) is out of the scope of this study.

Although several regional HI climatology studies have been published in the last 20 years (see $\mathrm{Lu}$ et al. 2011 and references therein), they all focus on North America, especially the US, where HI was originally defined. Each of these studies used temperature and dew point measured by radio sounding at different levels according to the limits of the variants. (Haines 1988; Winkler et al. 2007; Potter et al. 2008; Lu et al. 2011). For this study, we determined the limits of the Low and Mid variants of HI in the region by considering regional elevations and taking annual averages of atmospheric pressure at the station. Following Winkler et al. 2007, we used the elevation thresholds of $300 \mathrm{~m}$ for Low variant of $\mathrm{HI}$ and $1000 \mathrm{~m}$ for Mid variant of $\mathrm{HI}$. Because there were no high mountains in the area considered, the High variant of the index was not used.

The meteorological quantities presented in this section were simulated by using a re-analysis model and were not derived from radiosonde measurements. A 17-year analysis (2000 to 2016) of HI was performed by using gridded fields $\left(2.5^{\circ}\right.$ latitude $\times 2.5^{\circ}$ longitude $)$ from global re-analysis data developed by the European Centre for Medium-Range Weather Forecast's (ECMWF) ERA Interim model (Dee et al. 2011). 


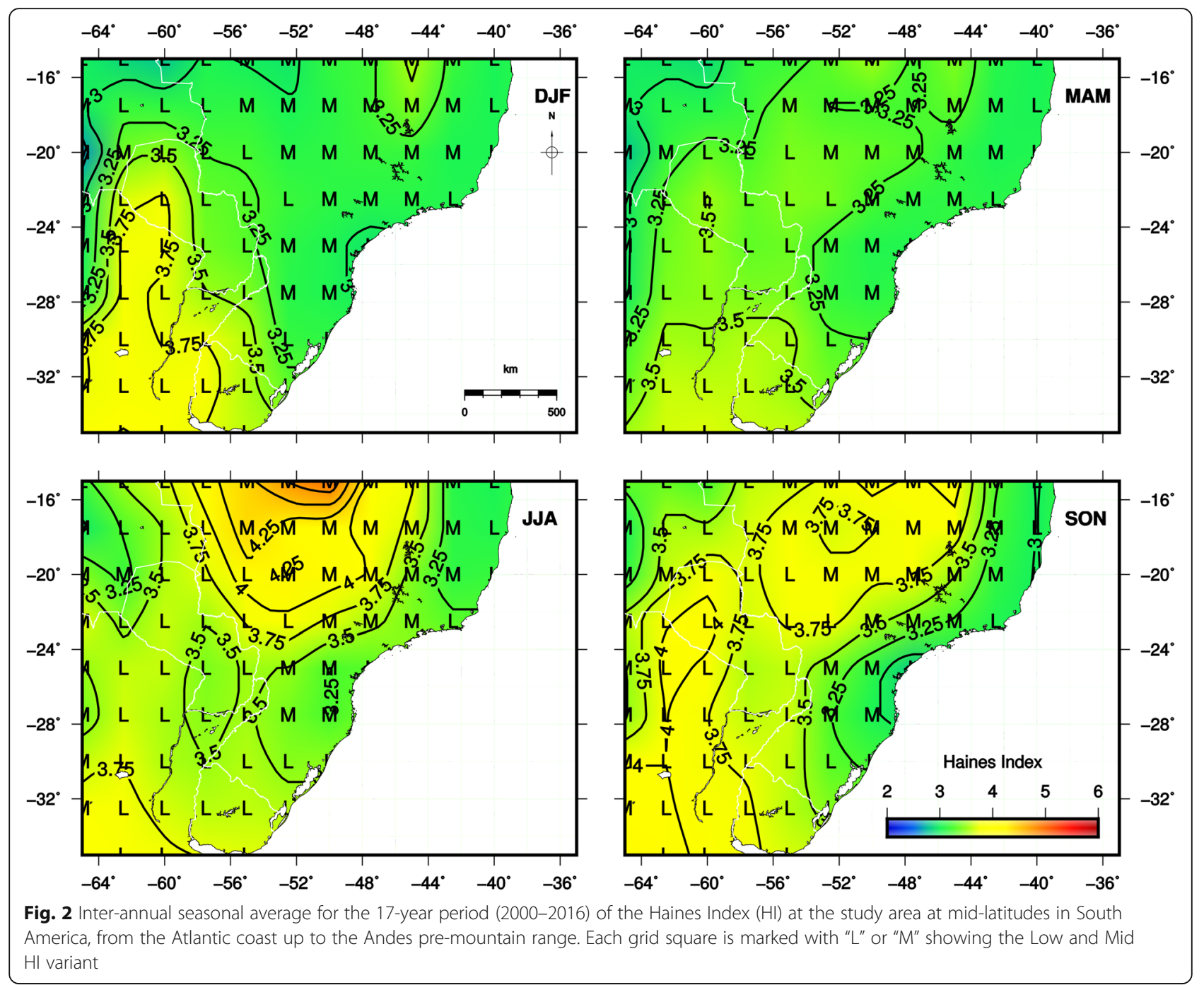

The ERA Interim model's re-analysis data included temperature and dew-point temperature at the mandatory pressure levels $(750 \mathrm{hPa}$ and $850 \mathrm{hPa})$ and the nonstandard level at $950 \mathrm{hPa}$. Gridded data was used instead of radiosonde observations because radio soundings were generally scarce in the region. Thus, multilevel daily mean values at 00:00 GMT were applied to compute seasonal, annual, and inter-annual averages and standard deviations. Moreover, based on previous climatological studies of HI (Winkler et al. 2007; Lu et al. 2011; Tatli and Türkes 2014), frequency and persistence measures were also included for index values greater than 4 (moderate, high, or very high potential of plume-dominated fires condition). Following $\mathrm{Lu}$ et al. (2011), "frequency" refers to the percentage of observations with $\mathrm{HI}$ greater than or equal to a given value, while "persistence" is understood to be the maximum number of consecutive days of $\mathrm{HI}$ greater than or equal to a given value during a given period.
Both $\mathrm{HI}$ and its terms atmospheric stability (hereafter, stability term) and moisture content (hereafter, moisture term) were computed at each re-analysis grid point.

From Fig. 2, we can see that, on average during these 17 years, the dry winter (June, July, August; JJA) and spring (September, October, November; SON) exhibited higher values than the warm summer season (December, January, February; DJF). The important contribution of the stability term to the inter-annual $\mathrm{HI}$ average is in the northeast part of the region, at Planalto Brasileiro (near $47^{\circ} \mathrm{W}$ and $15^{\circ}$ to $20^{\circ} \mathrm{S}$ ) and Serra da Canastra (near $46.3^{\circ}$ W and $20.25^{\circ} \mathrm{S}$ ), during the whole year. Nevertheless, the maximum stability term moved to the west in spring and summer (Fig. 3). The inter-annual average moisture term exhibited high values in the southwest of the selected region (i.e., at the center of Argentina, about $63^{\circ}$ to $65^{\circ} \mathrm{W}$ and $30^{\circ}$ to $35^{\circ} \mathrm{S}$, Sierras de Córdoba; Fig. 4).

From Fig. 5, in summer, high frequencies occur in the area of Paraguay, Uruguay, and the pre-mountain range 


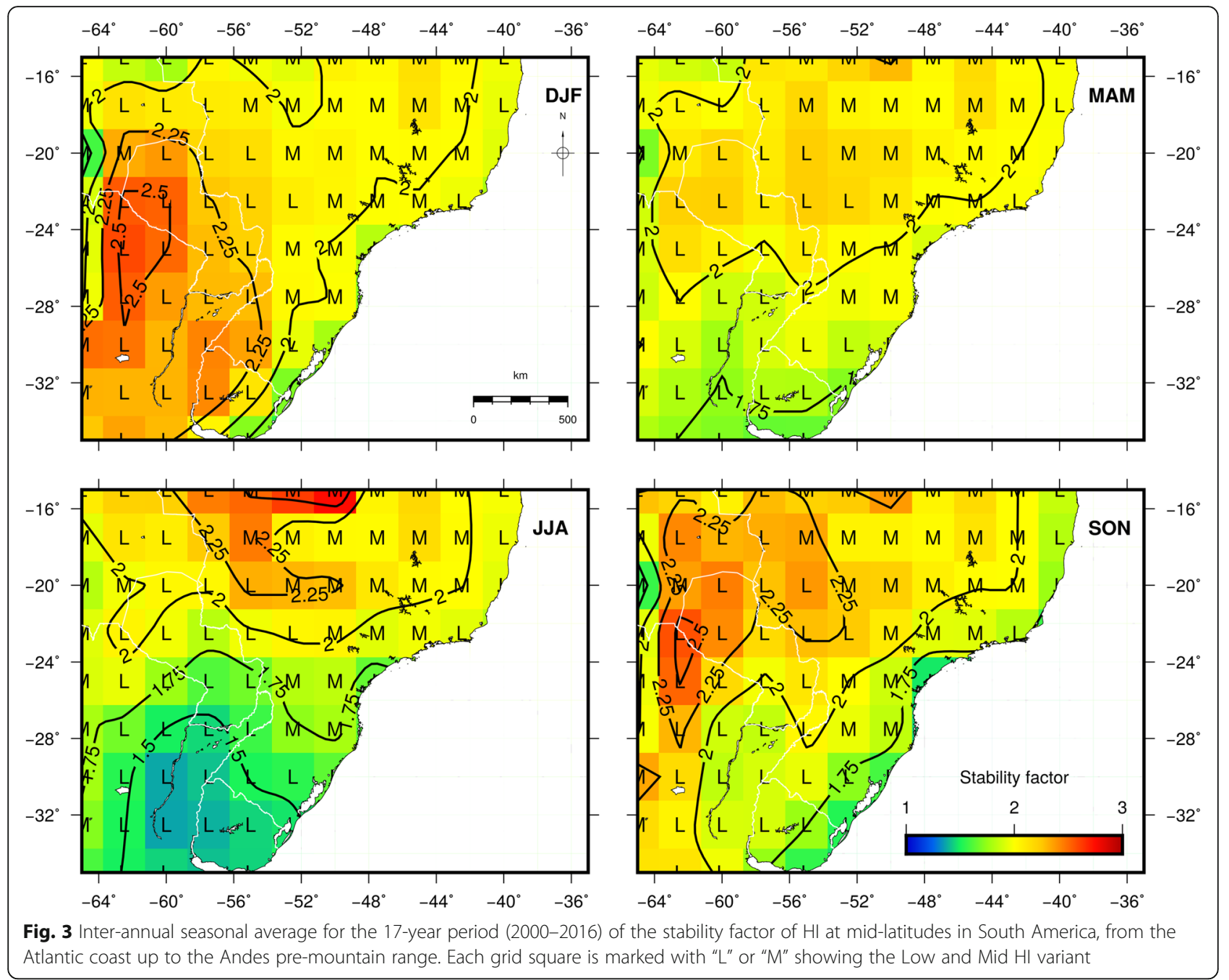

of the Andes in the central part of Argentina. The Andes pre-mountain range is a chain of small mountains located, north-to-south, from $29^{\circ} \mathrm{S}$ to $33.5^{\circ} \mathrm{S}$ at about $64.7^{\circ} \mathrm{W}$ in longitude (Río and Achával 1904), which we will refer to as "Sierras de Córdoba." However, the highest frequency values for $\mathrm{HI}(\geq 4)$ in Fig. 5 occurred from winter until spring, when the frequencies displayed a spatially symmetrical pattern with high values not only in the southwest of the region but also across the elevated region of Brazil, in the northeast of the selected area. Figure 6 displays the frequency values for $\mathrm{HI} \geq 5$ during the period 2000 to 2016, and it shows that the percentage of days with moderate or high $\mathrm{HI}$ values is only important during winter and spring. In particular, the maximum $\mathrm{HI}$ value appeared in the winter in the Brazilian highlands. Moreover, the spatially symmetrical pattern appeared again during spring, showing similar values in the highlands in Brazil and in the center of Argentina. The frequency of $\mathrm{HI}=6$ (not shown) only exhibits a maximum of around $20 \%$ in the Brazilian highlands in winter.

Figures 7 and 8 show the persistence in days during 2000 to 2016 for $\mathrm{HI} \geq 4$ and $\mathrm{HI} \geq 5$, respectively. In agreement with the previous results, Figs. 7 and 8 also exhibit maximum HI values in the Brazilian highlands during winter. Maximum values in the persistence of $\mathrm{HI}$ $=6$ (not shown) still appear at the Brazilian highlands, but only during winter. Nevertheless, these values never exceed 20 days.

We can conclude that two areas exist that persistently experienced high values of HI: Sierras de Córdoba (Argentina) during summer (DJF), and Serra da Canastra and central Planalto (Brazil) during winter and spring (JJA and SON).

Nevertheless, we should be careful about the interpretation of these results in the context of fire risk or fire hazard. On one hand, fire hazard considers potential fire behavior for a fuel type and is independent of the 


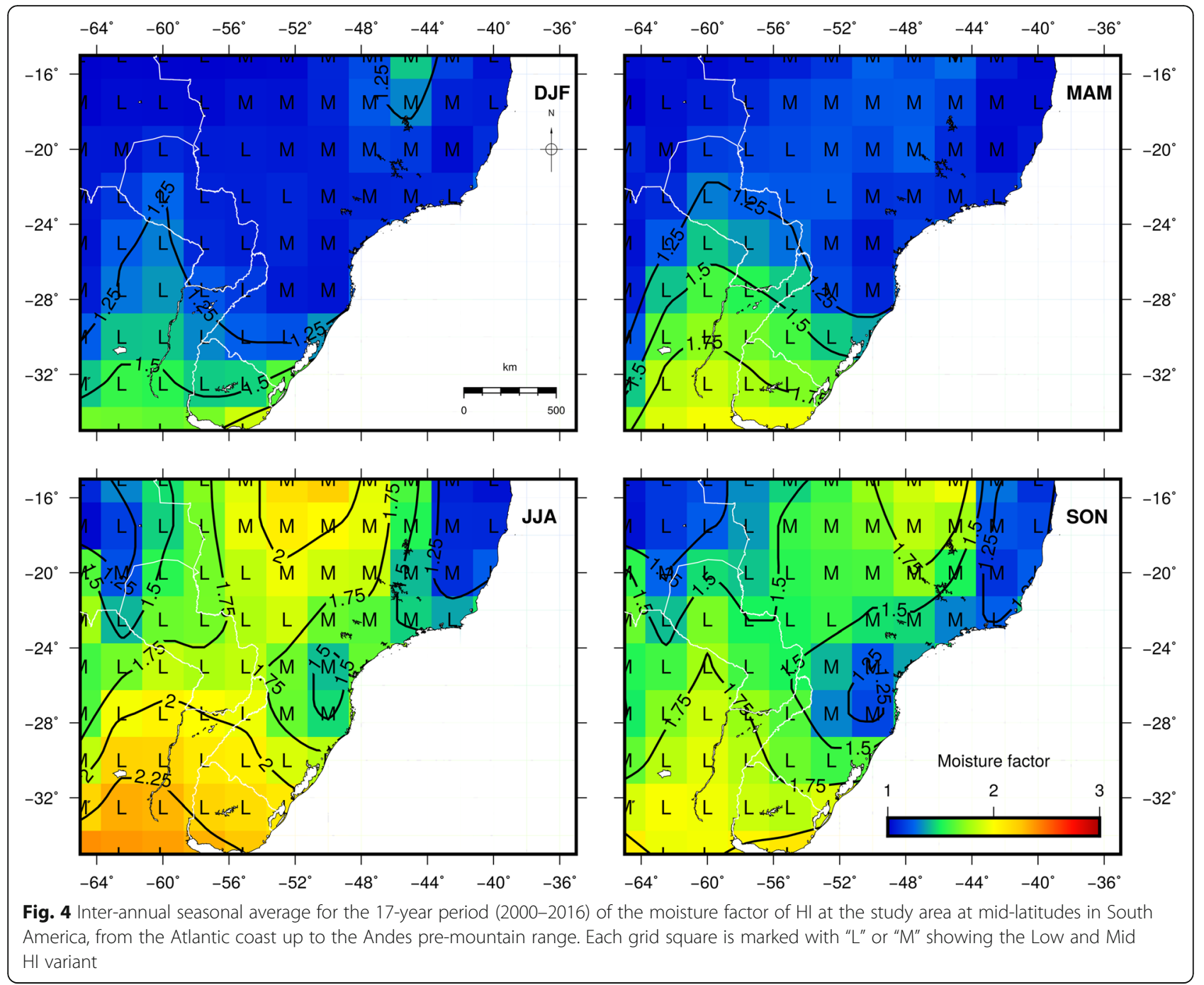

influence of weather on fuel-moisture content (Hardy 2005). On the other hand, fire risk refers only to the probability of ignition, both man- and lightning-caused (i.e., the chance that a fire might start; Hardy 2005.

Thus, results from the application of HI should be useful in the evaluation of crown fire potential. A crown fire is intense, fast moving, and destructive (Scott and Reinhardt 2001). According to these authors, hazard of crown fire is dependent upon the physical situations that lead to its occurrence. In particular, they result from a combination of factors altering the fire environment: fuel, weather, and slope steepness.

\section{The GPT2w model}

From the physical properties of radio signals from GNSS propagating in the atmosphere, it is possible to obtain a value for Integrated Water Vapor (IWV) by using GNSS receivers on land, or temperature and humidity profiles by using radio occultation techniques. The estimation of atmospheric parameters from GNSS observations and the subsequent use of those parameters in weather and climate studies defines the topic known as GNSS Meteorology. The first experiments employing these ground- or space-based GPS techniques were reported in the 1990s (Bevis et al. 1992; Kursinski et al. 1995). Today, many national weather services routinely use these measurements. For example, the national weather service of France has been using such data sets from European ground-based GPS networks and from satellites equipped with GPS radio occultation receivers for updating its operational weather prediction analyses since 2007 (Poli et al. 2008).

The GPT2w model was originally created for use in applications such as geodetic calculation of the zenithal wet delay of radio signals propagating in the atmosphere. GPT2 $w$ is an empirical geodetic model that provides hydrostatic and wet mapping function coefficients of the 


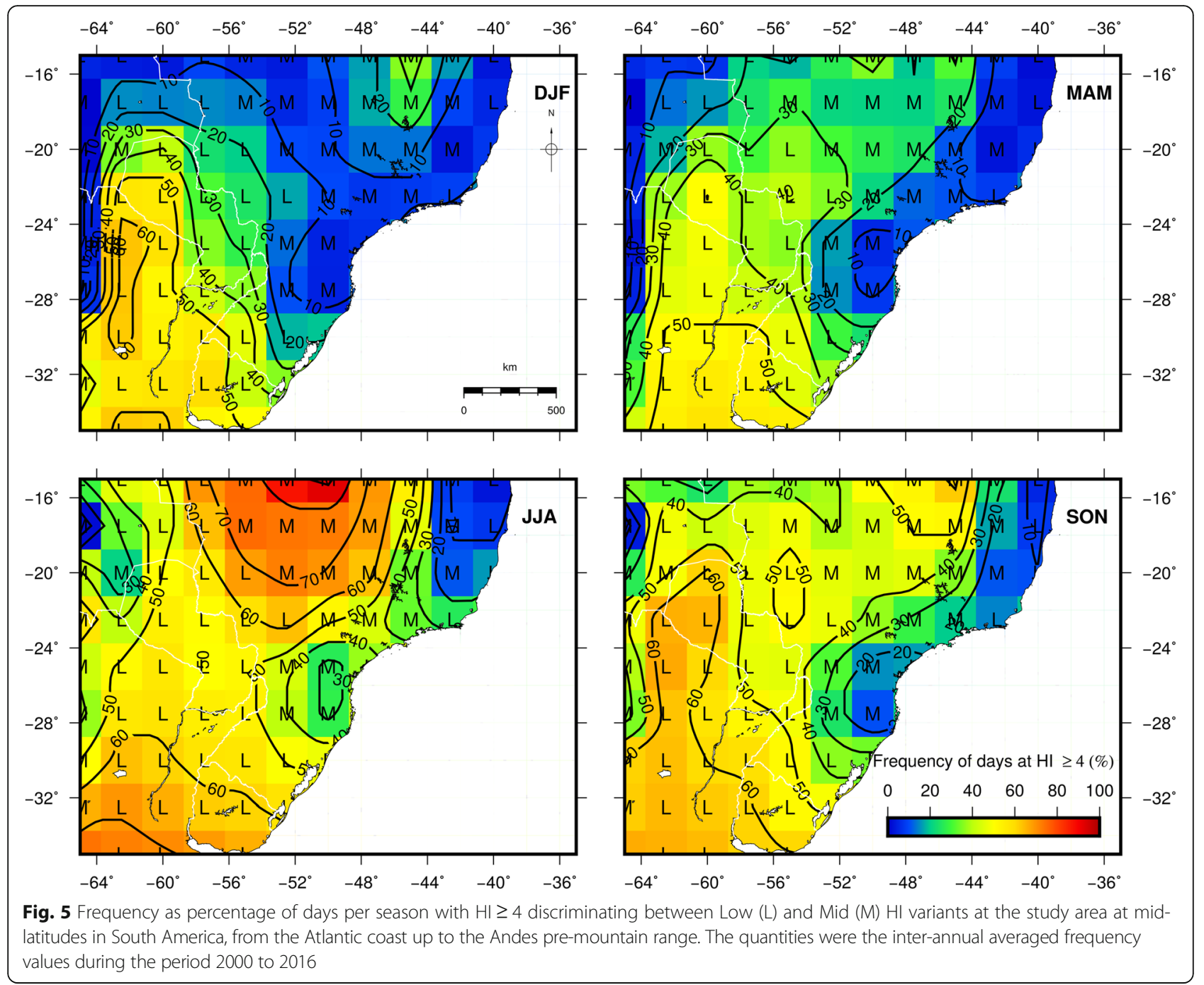

Vienna mapping function 1 (VMF1; Böhm et al. 2006). Additionally, knowing the Modified Julian Date (MJD) and the geodetic coordinates of the site, GPT2w can also provide atmospheric pressure, surface temperature and its vertical gradient, mean atmospheric temperature, and water vapor pressure and its vertical variation. It also has the ability to estimate annual and semi-annual components in their iterations. Since input to GPT2w software supports the time reference in MJD as a real number (i.e., with fractional part), it can be calculated at any time. Our application provides the meteorological parameters at hourly intervals.

The source of data used by GPT2w was 10-year monthly mean level pressure data from ERA Interim fields with $1^{\circ}$ horizontal resolution (Böhm et al. 2015). The latter condition made the model unable to represent small variations in the computed meteorological magnitudes. In these cases, GPT2w model was used to provide vertical gradients that were used to extrapolate temperature and dew-point temperature at different heights from surface meteorological measurements. Thus, even when these temperatures were estimates, they were closer to reality than any estimate made from a global climate model.

\section{Simulation of HI from GPT2w}

Local meteorological measurements (atmospheric pressure, $P_{\mathrm{s}}$; temperature, $T_{\mathrm{s}}$; relative humidity, $R H_{\mathrm{s}}$ ) at the Earth's surface, along with the respective radiosonde launch, were necessary for validation at each location. These data were obtained from the Integrated Global Radiosonde Archive (IGRA) version 2 web site (ftp://ftp. ncdc.noaa.gov/pub/data/igra). In each sounding, a second-level flag indicated that the surface parameters were measured.

By using the Clapeyron-Clausius equation (Parish and Putnam 1977; Brock and Richardson 2001), we can compute the saturation water vapor pressure $\left(e_{\mathrm{s}}^{\mathrm{s}}\right)$ at the sur- 




face as a function of $T_{\mathrm{s}}$ following the equation of Buck (1981) (in Brock and Richardson 2001: 87):

$$
e_{\mathrm{s}}^{\mathrm{S}}=6.1121 e^{\frac{17.502 T_{\mathrm{s}}}{T_{\mathrm{s}}+240.97}}
$$

where $T_{\mathrm{s}}$ is in degrees Celsius and $e_{\mathrm{s}}^{\mathrm{s}}$ is in hPa. Thus, by using surface relative humidity (\%), we obtained the water vapor pressure at surface $\left(e_{s}\right)$, in the same units as $\left(e_{\mathrm{s}}^{\mathrm{s}}\right)$ :

$$
e_{\mathrm{s}}=e_{\mathrm{s}}^{\mathrm{s}}\left(\frac{R H_{\mathrm{s}}}{100}\right)
$$

The calculation of the Haines Index needs air temperature at the 950, 850, 700 and $500 \mathrm{hPa}$ pressure levels, and dew-point temperatures at the 850 and $700 \mathrm{hPa}$ levels (see Table 1). Because we only compute the Low- and Mid-variant of the HI, we just used air temperature at the 950, 850, and $700 \mathrm{hPa}$ pressure levels, and dew-point temperatures at $850 \mathrm{hPa}$. Moreover, the model provides vertical gradients of temperature $(d T)$ and water vapor $(\lambda)$.

The vertical extrapolation of pressure by the GPT $2 w$ model relies on an exponential trend coefficient related to the inverse of the virtual temperature (Böhm et al. 2015: Equation 25), while the extrapolation of temperature is a linear isothermal scale height that utilizes the GPT2w temperature lapse rate $d T$.

From $\lambda$ we extrapolated the saturation water vapor pressure and the water vapor pressure on the target level (e.g., on $850 \mathrm{hPa}, e_{850}^{\mathrm{s}}$ and $e_{850}$; Böhm et al. 2015):

$$
e_{850}^{\mathrm{s}}=e_{\mathrm{s}}^{\mathrm{s}}\left(\frac{850 \mathrm{hPa}}{P_{\mathrm{s}}}\right)^{\lambda+1}
$$

and 




$$
e_{850}=e_{\mathrm{s}}\left(\frac{850 \mathrm{hPa}}{P_{\mathrm{s}}}\right)^{\lambda+1}
$$

Notice that the vertical extrapolation of $e^{\mathrm{s}}$ uses the GPT2w-inherent $\lambda$ values of the water vapor decrease factor. Even if the gridded ERA Interim data used to estimate the $\lambda$ parameter has a spacing of $1^{\circ}$ in latitude and longitude, horizontal resolution is not reduced toward coarser spacing because the wet part in the atmosphere has small-scale structures, particularly in coastal areas (Böhm et al. 2015). Nevertheless, Böhm et al. (2015) showed that it is not sufficient to apply constant decrease factors for water vapor pressure, neither in space nor in time due to the inherent variability of water vapor that could cause steep gradients of $\lambda$.

Afterwards, the air temperature at $850 \mathrm{hPa}\left(T_{850}\right)$ can be obtained by using either the temperature gradient from GPT2w or by inverting the equation of Buck (1981). Because the last alternative produces estimated values closer to $H I \_R$ values than the vertical gradients, the temperature was extrapolated as:

$$
T_{850}=\frac{240.97}{\left[\frac{17.502}{\ln \left(\frac{e_{850}^{\mathrm{s}}}{6.1121}\right)}-1\right]}
$$

where, again, $T_{850}$ is in degrees Celsius and $e_{850}^{\mathrm{s}}$ is in $\mathrm{hPa}$. Finally, the dew-point temperature at $850 \mathrm{hPa}\left(T_{850}^{\mathrm{d}}\right.$ ) can be estimated from Hardy (1998)):

$$
T_{850}^{\mathrm{d}}=\frac{\sum_{\mathrm{i}=0}^{3} c_{\mathrm{i}} \ln \left(e_{850}^{\mathrm{s}}\right)^{\mathrm{i}}}{\sum_{\mathrm{i}=0}^{3} d_{\mathrm{i}} \ln \left(e_{850}^{\mathrm{s}}\right)^{\mathrm{i}}},
$$

where $c_{0}=2.0798 \times 10^{2} ; c_{1}=-2.0156 \times 10 ; c_{2}=4.6779 \times$ 


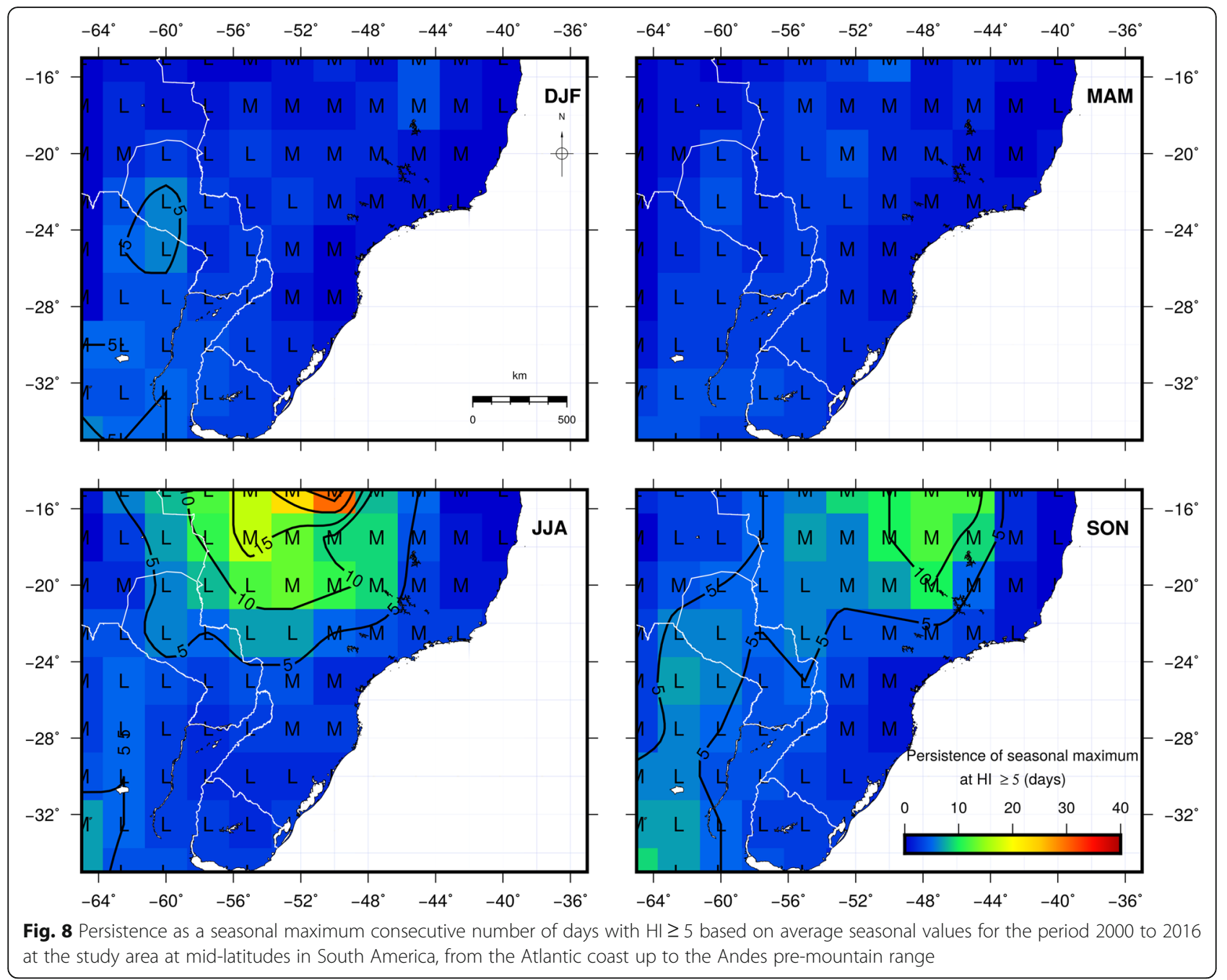

$10^{-1} ; \quad c_{3}=-9.2281 \times 10^{-6} ; \quad d_{0}=1 ; \quad d_{1}=-1.332 \times 10^{-1} ;$ $d_{2}=6.6578 \times 10^{-3}$; and $d_{3}=-7.5173 \times 10^{-5}$.

Once extrapolated values of temperature and dew-point temperature are at target levels, HI is estimated using the information found in Tables 1 and 2 . These simulated values are referred to as HI-GPT2w.

\section{Results}

The capacity and limitations of the GPT2w model in extrapolating vertical values of temperature $(T)$ and dew-point depression $(T D)$ are shown in Fig. 9, which compares seasonal mean values of $T$ and $T D$ for austral summer (DJF) and winter (JJA), estimated from GPT2w with the respective averages from radiosondes. From Fig. 9, we can see that the adiabatic vertical extrapolation of temperature by the model misrepresented dry air conditions as height increased, as expected. Maximum values of temperature differences reached $6.8{ }^{\circ} \mathrm{C}$ (DJF) and $8.4{ }^{\circ} \mathrm{C}$ (JJA), both at $700 \mathrm{hPa}$, although the standard deviation values for the model ranged from $3{ }^{\circ} \mathrm{C}$ (DJF) to
$4{ }^{\circ} \mathrm{C}$ (JJA), and, for the radiosondes measurements, ranged from $2.5{ }^{\circ} \mathrm{C}$ (DJF) to $4.5{ }^{\circ} \mathrm{C}$ (JJA). Such inaccuracies would produce some inconsistencies in the stability term of HI. On the other hand, dew-point temperature differences between radiosondes and GPT2w estimations were on the order of 1.2 to $2.7^{\circ} \mathrm{C}$ (DJF) and 0.6 to $6.9^{\circ} \mathrm{C}$ (JJA), with standard deviations values rising as height increased, and reached more than $10{ }^{\circ} \mathrm{C}$ for both datasets.

In order to quantify how such differences impacted HI computation, the results of HI-GPT2w were validated at 17 radiosondes stations (Table 2) during 2016. This period was chosen for the radiosondes data availability at the selected area. Among the selected stations was Córdoba (Table 2), located in one of the danger areas (Sierras de Córdoba). Although the model supports calculation for short time intervals, depending on the availability of the data (e.g., hourly), we chose to make calculations (HI-GPT2w) at daily intervals to be able to compare with the radiosonde values. 

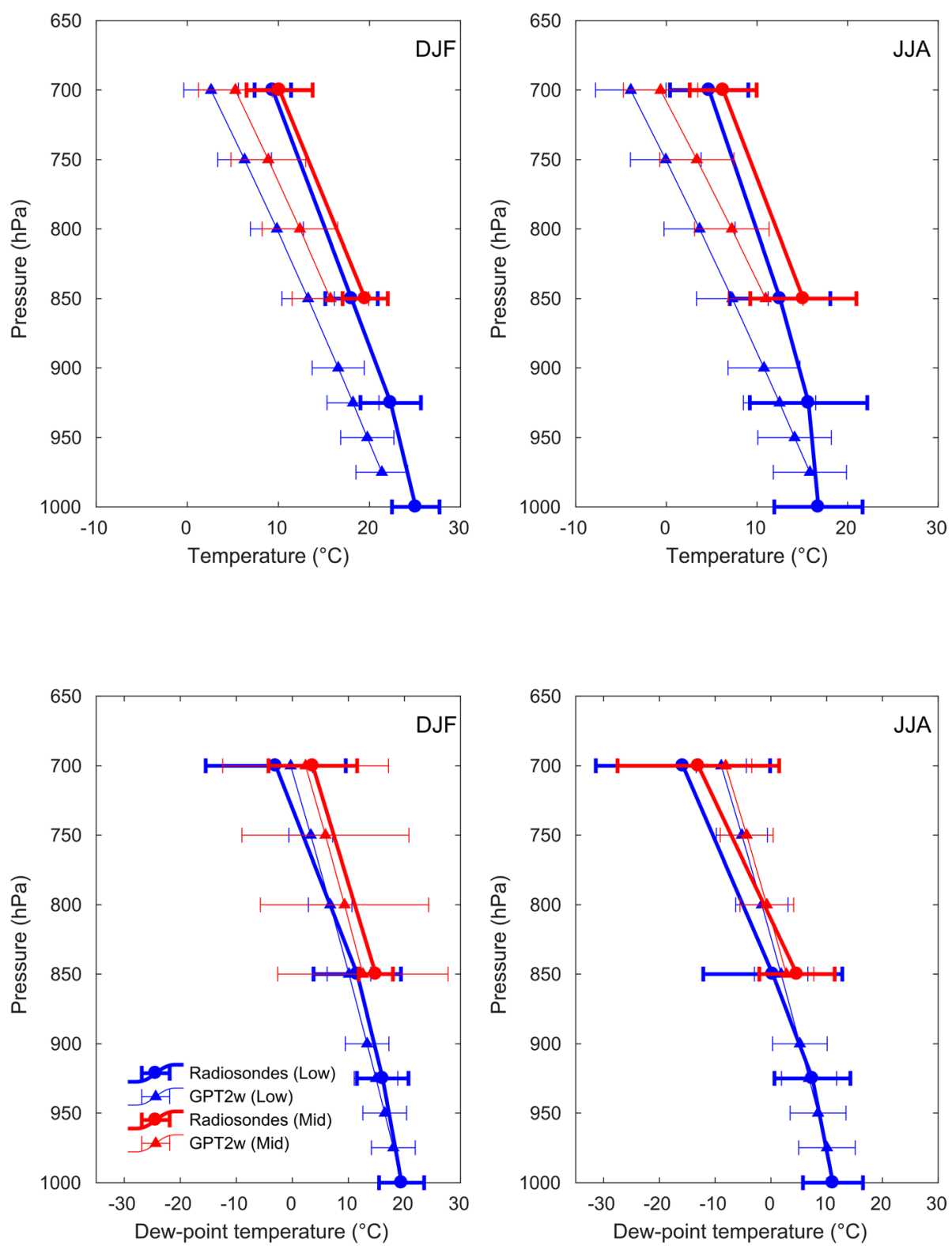

Fig. 9 The seasonal mean of temperature and dew-point temperature values for the period 2000 to 2016 at the study area at mid-latitudes in South America, from the Atlantic coast up to the Andes pre-mountain range, estimated from GPT2W $(\boldsymbol{\Delta})$ compared against the respective seasonal average values from the radiosonde profiles $(\bullet)$. Two cases are shown at each plot: the Low-variant HI stations (in blue) and the Mid-variant $\mathrm{HI}$ stations (in red)

HI values were derived from radiosonde measurements $(H I$ R $)$ by using available data (IGRA version 2, $\mathrm{ftp}: / / \mathrm{ftp}$. ncdc.noaa.gov/pub/data/igra). Notice that, after Potter et al. (2008)), who claimed that the direct substitution of the $925 \mathrm{hPa}$ temperature for the $950 \mathrm{hPa}$ temperature can dramatically underestimate potential wildfire severity estimated by the $\mathrm{HI}$, the radiosonde measurements at $950 \mathrm{hPa}$ level were interpolated from the mandatory level at $925 \mathrm{hPa}$. Thus, the log-pressure interpolation followed Potter et al. (2008) and used surface and $925 \mathrm{hPa}$ level data to obtain the temperature at $950 \mathrm{hPa}$ for Low-variant HI stations.

To be able to evaluate at first glance the performance of GPT2w in replicating the radiosondes measurements, we showed both time series of the HI together. Figure 10 shows HI_R superimposed on HI-GPT2w during 2016 at six chosen stations: three representing the Low HI variant (LHI) and other three for the Mid HI variant (MHI). On one hand, we can see that LHI (SAEZ, SBGL, SBFL; Table 2) never exceeded 5 at the selected stations and 


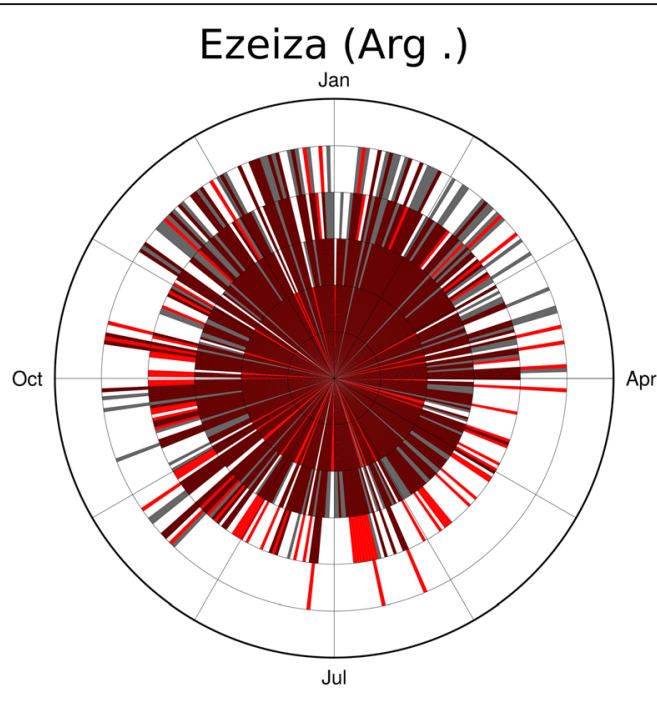

Galeao (Bra.)



Florianópolis (Bra.)

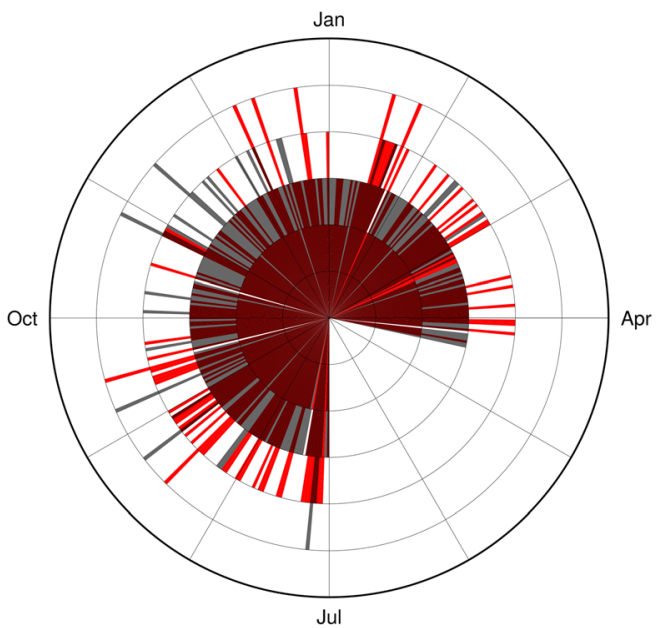

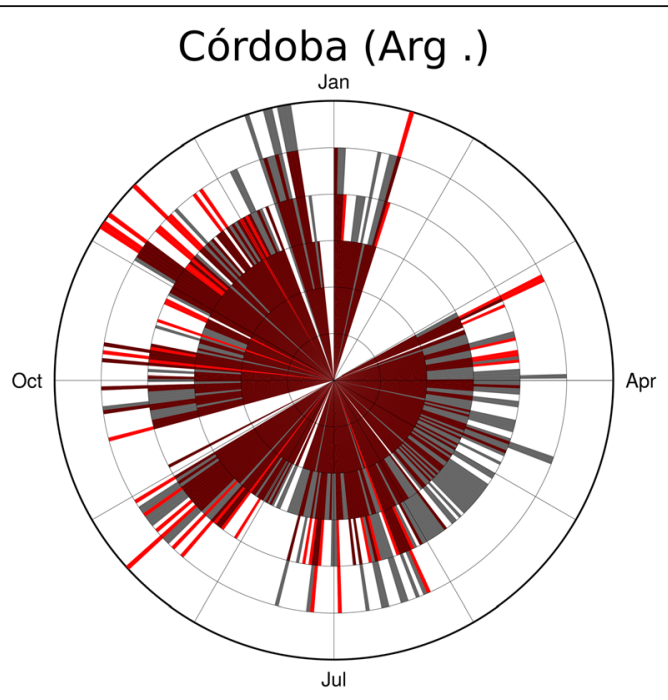

Campo Grande (Bra.)

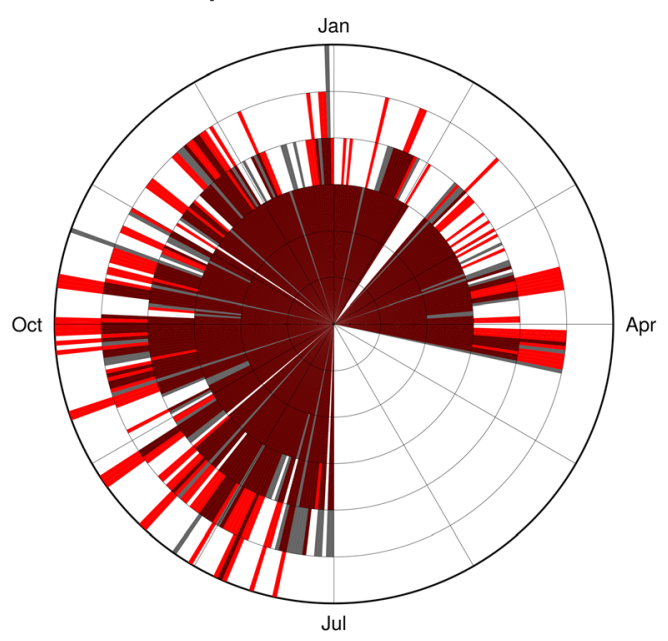

Marte Civ/Mil (Bra.)

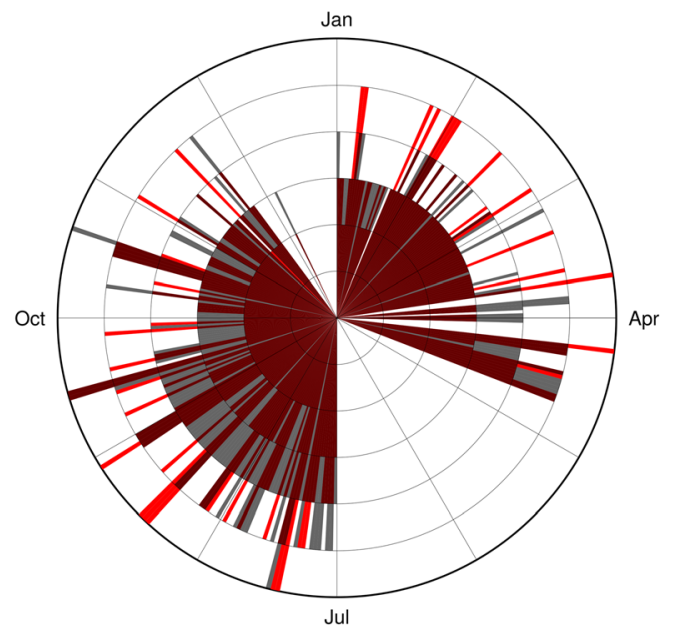

Fig. 10 (See legend on next page.) 
(See figure on previous page.)

Fig. 10 Haines Index values computed from radiosonde measurements for six stations at the study area at mid-latitudes in South America, from the Atlantic coast up to the Andes pre-mountain range, during 2016 (HI_R, in red) superimposed on the Haines Index values from the GPT2W model simulation (HI_GPT2W, in gray). Values are shown similar to a wind rose, where the HI values 2 through 6 correspond to the concentric circles, with 6 being the outermost circle, and the date of each observation corresponds to the direction of the red or gray lines, clockwise from January to December. Low-variant HI stations are shown in the left column and include stations in Ezeiza, Argentina; Galeao, Brazil; and Florianópolis, Brazil. Mid-variant HI stations are shown in the right column and include stations in Cordoba, Argentina; Campo Grande, Brazil; and Marte Civ/Mil, Brazil. Notice that Low-variant values never reach $\mathrm{HI}=6$

the model frequently underestimated $H I \_R$ values. In contrast, the MHI stations (SACO, SBCG, SBMT; Table 2) often reached maximum index values. Here again, the underestimation of the model was noticeable.

The total percentage $(\mathrm{HI}=2, \ldots, 6)$ of hits was $57.03 \%$ for LHI and 50.12\% for MHI (Table 3 and Fig. 11). The best performance was for very low values ( $\mathrm{HI}=2$ to 3 ) for both variants. Notice that there were almost no cases of $\mathrm{LHI}=6$. The underestimation of GPT2w was 25 to $26.3 \%$, and similar for both variants, showing the worst cases for $\mathrm{LHI}=4$ (low $\mathrm{HI}$ values, Low variant) and $\mathrm{MHI}$ = 5 (moderate $\mathrm{HI}$ values, Mid variant). The total overestimation $(\mathrm{HI}=2, \ldots, 6)$ was clearly worse for MHI (24.83\%).

In general, it was clear that the success of the GPT2w model in replicating $H I$ R fell as $\mathrm{HI}$ values grew. Moreover, the main failure detected was an underestimation for Low HI variant (26.28\%) while, for the Mid HI variant, the total percentage of underestimation (25.05\%) and overestimation (24.84\%) was quite similar.

Table 3 Percentages of the efficiency of the GPT2w simulation used to build the Low-variant Haines Index (LHI) and the Midvariant Haines Index (MHI) during 2016 at the stations at the study area at mid-latitudes in South America, from the Atlantic coast up to the Andes pre-mountain range, listed in Table 2. Results are classified according to the Haines Index values (from 2 to 6); percentage of hits is in boldface. Note that LHI never reaches the maximum value of 6

\begin{tabular}{|c|c|c|c|}
\hline \multirow[b]{2}{*}{ Haines Index value } & \multirow[b]{2}{*}{ Accuracy of $\mathrm{HI}$} & \multicolumn{2}{|c|}{ Simulation efficiency (\%) } \\
\hline & & $\mathrm{LHI}$ & $\mathrm{MHI}$ \\
\hline \multirow[t]{3}{*}{2 to 3 Very low } & Underestimation & $0.00 \%$ & $0.00 \%$ \\
\hline & Hit & $43.33 \%$ & $29.72 \%$ \\
\hline & Overestimation & $11.58 \%$ & $17.72 \%$ \\
\hline \multirow[t]{3}{*}{4 Low } & Underestimation & $18.22 \%$ & $6.12 \%$ \\
\hline & Hit & $8.85 \%$ & $7.93 \%$ \\
\hline & Overestimation & $3.86 \%$ & $5.89 \%$ \\
\hline \multirow[t]{3}{*}{5 Moderate } & Underestimation & $8.06 \%$ & $14.63 \%$ \\
\hline & Hit & $4.85 \%$ & $10.02 \%$ \\
\hline & Overestimation & $0.00 \%$ & $1.22 \%$ \\
\hline \multirow[t]{2}{*}{6 High } & Underestimation & $0.05 \%$ & $4.30 \%$ \\
\hline & Hit & & $2.45 \%$ \\
\hline
\end{tabular}

To explain the origin of the mismatches, we analyzed the simulation of the stability and moisture terms for each $\mathrm{HI}$ value from 2 to 6 . Figure 12 shows the difference between the aforementioned terms from radiosonde and the GPT2w simulation versus the number of days (stability term in green and moisture term in blue). The results are displayed according to Low-variant HI (left) and Mid-variant HI (right). For the Low HI variant (Fig. 12, left column) the underestimation at $\mathrm{LHI}=3,4$, and 5 was due to the moisture term, while stability was responsible for the overestimation of the index at $\mathrm{LHI}=$ 2 and 4. For the Mid variant (Fig. 12, right column), in general, the stability term appears to have caused overestimation at $\mathrm{MHI}=2$ and underestimation at $\mathrm{MHI}=5$ and 6. Nevertheless, the contribution of both terms seems to be similar for $\mathrm{MHI}=4$.

\section{Discussion and conclusions}

This study addressed two main objectives. The first was to characterize the climatological behavior of $\mathrm{HI}$ in a selected region of South America in order to detect areas prone to plume-dominated fires. The chosen region covered most of the Río de La Plata drainage basin and included, in the southwest, part the pre-mountain range of the Andes (central part of Argentina, Sierras de Córdoba) and the northern part of the Planalto Brasileiro, Serra da Canastra in Brazil. This study area in South America was selected for its availability of radiosonde launches at 00:00 GMT during the year 2016. The behavior of the index was characterized through an investigation of the climatology of the HI by using ERA Interim data for the period 2000 to 2016. We identified two areas that persistently experienced high values of HI: Sierras de Córdoba (Argentina) during summer (DJF), and Serra da Canastra and central Planalto (Brazil) during winter and spring (JJA and SON).

The second objective was to test the application of the GPT2w model, which has the capacity to generate vertical gradients of different meteorological parameters and therefore can simulate the construction of HI. The application of GPT2w was suggested due to the notable lack of radiosondes in large regions of South America that are often subjected to extensive fires, some of which are man made (Argañaraz et al. 2015). The simulated values of $\mathrm{HI}$ computed from the GPT2w model (HI_GPT2w) were 

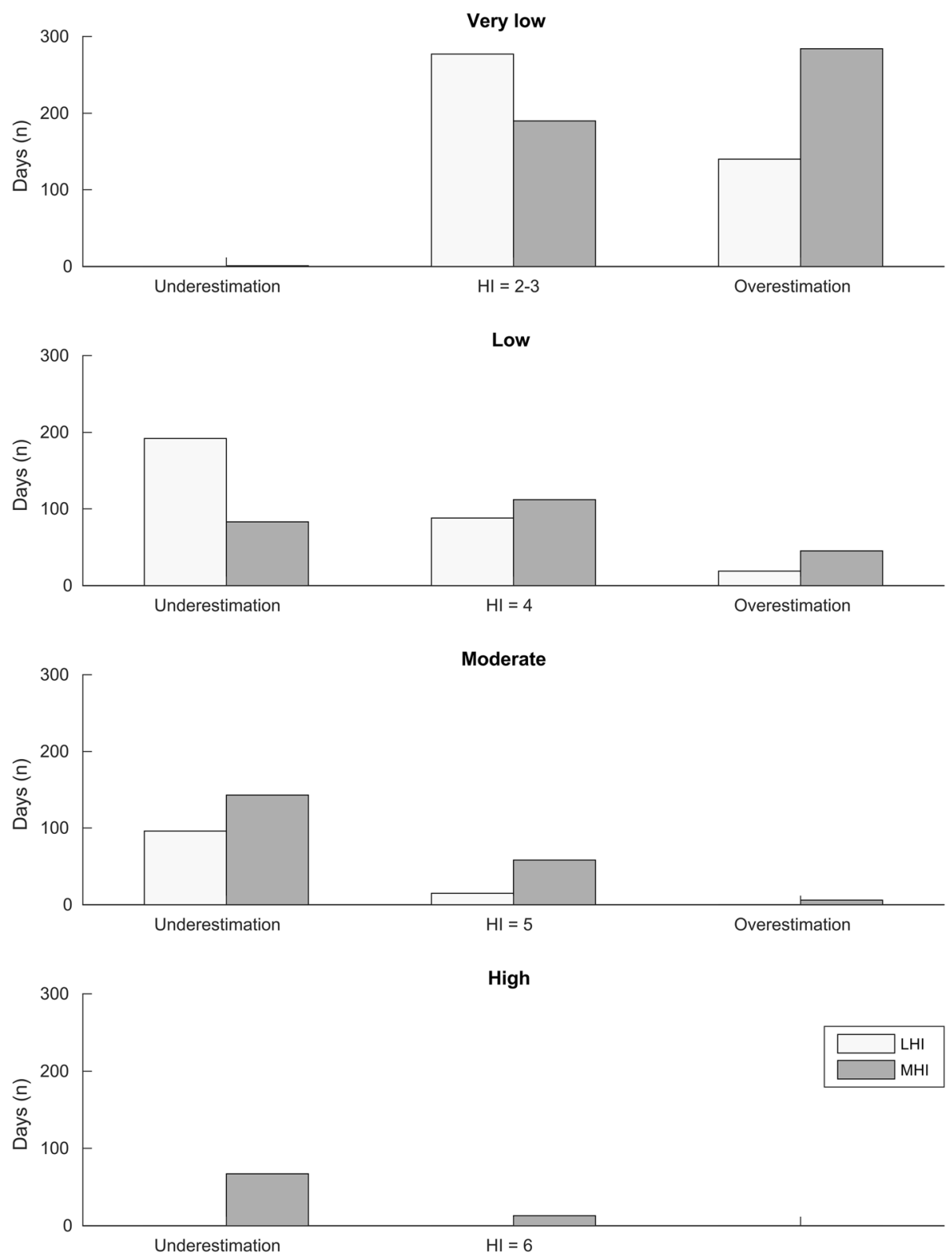

Fig. 11 Performance of the simulation (HI_GPT2W) in reproducing HI from radiosonde measurements (HI_R) during 2016 at the study area at mid-latitudes in South America, from the Atlantic coast up to the Andes pre-mountain range, as a number of days of successes and failures. LHI and $\mathrm{MHI}$ refer to the Low and Mid variant of HI, respectively

compared with values of $\mathrm{HI}$ computed from measured radio-sounding data $(H I-R)$ during 2016. HI_GPT2w reproduced $H I-R$ about $50 \%$ of the time, more accurately for very low $\mathrm{HI}$ values $(\mathrm{H}=2$ to 3$)$ than for high values $(\mathrm{HI}=6)$. The lack of agreement in the moisture term caused an underestimation of the Low-variant HI values (LHI), while the stability term was responsible for the lack of coincidence in Mid-variant HI values (MHI).

Although the model can also simulate meteorological data at the Earth's surface and vertically extrapolate them, in order to obtain more realistic values, meteorological data measured on the surface were used. Thus, the model was only applied to find the gradients that allowed us to extrapolate saturated water vapor pressure and air temperature at a given pressure level.

El Niño (EN) events are responsible for the rainy season in most of Brazil, and this is because EN affects the tropical heat sources and global atmospheric circulation that impact the South America summer monsoon (Grimm 2003). The last 2015-2016 El Niño was one of the strongest EN events ever recorded (Jiménez-Muñoz et al. 2016, Paek et al. 2017) Based on the Oceanic Niño Index (ONI), 



Fig. 12 Differences between stability factors (in green) computed from radiosonde measurements (R) and simulated from GPT2W (GPT2W) as a function of the number of days during 2016 at the study area at mid-latitudes in South America, from the Atlantic coast up to the Andes premountain range. Differences between moisture factors are plotted in blue. The results for Low-variant HI are shown in the left column and for Mid-variant $\mathrm{HI}$ in the right column

an application of the 3-month running mean of the sea-surface temperature anomalies in the El Niño 3.4 region, we can detect that warm anomalies started at the end of 2014 and remained up until austral fall of 2016. Nevertheless, there was a slight La Niña phase at the end of 2016. (http://origin.cpc.ncep.noaa.gov/products/analysis_monitoring/ensostuff/ONI_v5.php). Normally, EN conditions affect the northern part of Brazil, causing droughts in the eastern Amazonia and unusually high precipitation in western Amazonia. Nevertheless, the 2015
-2016 event was extremely hot and this extreme heat coincided with an increased extent of extreme drought severity from precipitation deficit through an increase in potential evapotranspiration (Jiménez-Muñoz et al. 2016). According to Jiménez-Muñoz et al. 2016, the impact of this situation on tree mortality and biomass growth may be attributed not only to precipitation deficits but also to heat stress. Moreover, fires had been suggested as a major agent of forest transition under drought. This particular situation affected the northern part of the selected area 
where maximum values of $\mathrm{HI}$ were reached. Alternatively, EN conditions for the southern part of the region (southern Brazil, Uruguay, northeastern Argentina) showed higher than average rainfall from November to the following January (Ropelewski and Halpert 1987). This situation is also represented in our results with typical values of $\mathrm{HI}$ $=2$ to 3 in this area.

In this study, we did not analyze the efficiency of HI linked to the occurrence of large or erratic wildfires. The crown fire hazard assessment needs not only a climatological study of the area, but also an analysis of soil and vegetation, (i.e., available fuel, fuel type, and terrain slope, among other characteristics; Scott and Reinhardt 2001, Mölders 2008). Moreover, for a complete evaluation of the potential that a convective fire will grow, HI should be evaluated together with another energy release index (Dentoni and Muñoz 2012

We conclude that the simple application of GPT2w to extrapolate the vertical values of temperature and its dew-point depression is not enough to reproduce $\mathrm{HI}$ as if it were derived from radiosonde measurements. In particular, it is important to notice that only the Buck (1981) model was applied to obtain saturation water vapor pressure at a given geopotential level. Therefore, this estimate could be improved with the application of other equivalent formulas, as summarized by the works of Alduchov and Eskridge (1996) or Kämpfer (2013): Appendix B). Moreover, with regard to the vertical propagation gradients, it is speculated that the extrapolated saturation water vapor pressure could be improved by using values of Integrated Water Vapor from Global Navigation Satellite System (GNSS-IWV) estimated at several stations in the region (Bianchi et al. 2016). Nevertheless, this last strategy has yet to be explored.

\section{Acknowledgements}

The authors thank the two anonymous reviewers for their careful reading of our manuscript and for their comments and suggestions that highly improved our work. We would like to thank the people, organizations, and agencies responsible for collecting, computing, maintaining, and openly providing the observations and products employed in this work: the European Centre for Medium-Range Weather Forecasts (ECMWF) for providing the ERA-Interim re-analysis data (http://apps.ecmwf.int/datasets/), and the Integrated Global Radiosonde Archive (IGRA, version 2) for providing the radiosondes measurements (ftp://ftp.ncdc.noaa.gov/pub/data/igra). We also thank J. Böhm from the Department of Geodesy and Geoinformation, TU Wien, (Vienna University of Technology, Austria) for providing the GPT2w model (http://ggosatm.hg.tuwien.ac.at/DELAY/SOURCE/GPT2w/).

\section{Funding}

This research was supported by the National Scientific and Technical Council of Argentina (CONICET) PIP 112-201201-00292 and La Plata National University (UNLP) project 11G/142.

\section{Availability of data and materials}

Please contact author for data requests.

\section{Authors' contributions}

L.I. Fernández led the study; contributed to data collection, analysis, and interpretation; and co-wrote the paper. J.M. Aragón Paz contributed to data collection analysis and interpretation and co-wrote the paper. A.M. Meza contributed to the statistical analysis and interpretation of the results. L.P.O. Mendoza contributed to data analysis and interpretation of the results. All authors read and approved the final manuscript.

\section{Authors' information}

L.I. Fernández is a professor in Spherical Astronomy and researcher in the field of GNSS Meteorology. J.M. Aragón Paz is a postgraduate student in Geophysics. A.M. Meza is a professor in Statistics and researcher in the field of Space Weather. L.P.O. Mendoza is a researcher in the field of Space Geodesy.

Ethics approval and consent to participate

Not applicable.

\section{Consent for publication}

Not applicable.

\section{Competing interests}

The authors declare that they have no competing interests.

\section{Publisher's Note}

Springer Nature remains neutral with regard to jurisdictional claims in published maps and institutional affiliations.

Received: 6 September 2018 Accepted: 19 September 2018

Published online: 22 March 2019

\section{References}

Alduchov, O.A., and R.E. Eskridge. 1996. Improved magnus form approximation of saturation vapor pressure. Journal of Applied Meteorology 35: 601-609. https:// doi.org/10.1175/1520-0450(1996)035\%3C0601:IMFAOS\%3E2.0.CO;2.

Argañaraz, J.P., G.J. Pizarro, M. Zak, and L.M. Bellis. 2015. Fire regime, climate, and vegetation in the Sierras de Córdoba, Argentina. Fire Ecology 11 (1): 55-73. https://doi.org/10.4996/fireecology.1101055.

Bevis, M., S. Businger, T.A. Herring, C. Rocken, R.A. Anthes, and R.H. Ware. 1992. GPS meteorology: remote sensing of atmospheric water vapor using the Global Positioning System. Journal of Geophysical Research: Atmospheres 97 (D14): 15787-15801. https://doi.org/10.1029/92JD01517.

Bianchi, C.E., L.P.O. Mendoza, L.I. Fernández, M.P. Natali, A.M. Meza, and J.F. Moirano. 2016. Multi-year GNSS monitoring of atmospheric IW over Central and South America for climate studies. Annales Geophysicae 34: 623-639. https://doi.org/10.5194/angeo-34-623-2016.

Böhm, J., G. Möller, M. Schindelegger, G. Pain, and R. Weber. 2015. Development of an improved empirical model for slant delays in the troposphere (GPT2w). GPS Solutions 19 (3): 433-441. https://doi.org/10.1007/s10291-014-0403-7.

Böhm, J., B. Werl, and H. Schuh. 2006. Troposphere mapping functions for GPS and very long baseline interferometry from European Centre for MediumRange Weather Forecasts operational analysis data. Journal of Geophysical Research 111: B02406. https://doi.org/10.1029/2005JB003629.

Brock, F.V., and S.J. Richardson. 2001. Meteorological measurement systems. New York: Oxford University Press.

Buck, A.L. 1981. New equations for computing vapor pressure and enhancement factor. Journal of Applied Meteorology and Climatology 20: 1527-1532. https:// doi.org/10.1175/1520-0450(1981)020<1527:NEFCVP>2.0.CO;2.

Caffera, R.M., and E.H. Berbery. 2006. Climatología de la Cuenca del Plata (Capítulo II). In El cambio climático en la Cuenca del Plata, ed. V. Barros, R. Clarke, and P. Silva Dias, 19-38. Buenos Aires: CONICET [In Spanish.].

Dee, D.P., S.M. Uppala, A.J. Simmons, P. Berrisford, P. Poli, S. Kobayashi, U. Andrae, M.A. Balmaseda, G. Balsamo, P. Bauer, P. Bechtold, A.C.M. Beljaars, L. van de Berg, J. Bidlot, N. Bormann, C. Delsol, R. Dragani, M. Fuentes, A.J. Geer, L. Haimberger, S.B. Healy, H. Hersbach, E.V. Hölm, L. Isaksen, P. Köllberg, M. Köhler, M. Matricardi, A.P. McNally, B.M. Monge-Sanz, J.J. Morcrette, B.K. Park, C. Peubey, P. de Rosnay, C. Tavolato, J.N. Thépaut, and F. Vitart. 2011. The ERA-Interim reanalysis: configuration and performance of the data assimilation system. Quarterly Journal of the Royal Meteorological Society 137 (656): 553-597. https://doi.org/10.1002/qj.828.

Dentoni, M.C, and Muñoz M.M. 2012. Sistemas de evaluación de peligro de incendios. Informe Técnico $N^{\circ}$ 1. Plan nacional de manejo del fuego. Programa Nacional de Evaluación de Peligro de Incendios y Alerta Temprana, Esquel, Chubut, Argentina. [In Spanish.] 
Enz, J.W, V. Hofman, and A. Thostenson. 2017. Air temperature inversions: causes, characteristics and potential effects on pesticide spray drift. North Dakota State University Extension Service-AE1705 revised. <https://www.ag.ndsu. edu/publications/crops/air-temperature-inversions-causes-characteristics-andpotential-effects-on-pesticide-spray-drift/ae1705.pdf>. Accessed Nov 2018.

Grimm, A.M. 2003. The El Niño impact on the summer monsoon in Brazil: regional processes versus remote influences. Journal of Climate 16: 263-280. https://doi.org/10.1175/1520-0442(2003)016\%3C0263:TENIOT\%3E2.0.CO;2.

Haines, D.A. 1988. A Lower Atmosphere Severity Index for wildland fires. National Weather Digest 13: 23-27

Hardy, B. 1998. ITS-90 formulations for vapor pressure, frost point temperature, dew point temperature, and enhancement factors in the range -100 to +100 C. In Proceedings of the third international symposium on humidity and moisture, 214-222. London: National Physics Laboratory, Teddington.

Hardy, C.C. 2005. Wildland fire hazard and risk: problems, definitions, and context. Forest Ecology and Management 211: 73-82. https://doi.org/10.1016/j.foreco.2005.01.029.

Jiménez-Muñoz, J.C., C. Mattar, J. Barichivich, A. Santamaría-Artigas, K. Takahashi, Y. Malhi, J.A. Sobrino, and G. van der Schrier. 2016. Record-breaking warming and extreme drought in the Amazon rainforest during the course of El Niño 2015-2016. Scientific Reports 6: 33130. https://doi.org/10.1038/srep33130.

Kämpfer, N., editor. 2013. Monitoring atmospheric water vapour. Ground-based remote sensing and in-situ methods. Volume 10. Springer, NewYork. doi https://doi.org/10.1007/978-1-4614-3909-7

Kursinski, E.R., G.A. Hajj, K.R. Hardy, L.J. Romans, and J.T. Schofield. 1995. Observing tropospheric water vapor by radio occultation using the Global Positioning System. Geophysical Research Letters 22 (17): 2365-2368. https://doi.org/10. 1029/95GL02127.

Lu, W., J.J. Charney, S. Zhong, X. Bian, and S. Liu. 2011. A North American regional reanalysis climatology of the Haines Index. International Journal of Wildland Fire 20: 91-103.

Mills, G.A., and L. McCaw. 2010. Atmospheric stability environments and fire weather in Australia: extending the Haines Index. Melbourne: Centre for Australian Weather and Climate Research, CAWCR Technical Report No. 20.

Mölders, N. 2008. Suitability of the Weather Research and Forecasting (WRF) model to predict the June 2005 fire weather for interior Alaska. Weather and Forecasting 23 (5): 953-973. https://doi.org/10.1175/2008WAF2007062.1.

Paek, H., J.-Y. Yu, and C. Qian. 2017. Why were the 2015/2016 and 1997/1998 extreme El Niños different? Geophysical Research Letters 44 (4): 1848-1856. https://doi.org/10.1002/2016GL071515.

Parish, O.O., and T.W. Putnam. 1977. Equations for the determination of humidity from dewpoint and psychrometric data. Washington, D.C: National Aerodynamics and Space Administration Technical Note NSAN TN D-8401.

Peel, M.C., B.L. Finlayson, and T.A. McMahon. 2007. Updated world map of the Köppen-Geiger climate classification. Hydrology and Earth System Sciences 11 (5): 1633-1644. https://doi.org/10.5194/hess-11-1633-2007.

Pettinari, M.L., R.D. Ottmar, S.T. Prichard, A.G. Andreu, and E. Chuvieco. 2013. Development and mapping of fuel characteristics and associated fire potentials for South America. International Journal of Wildland Fire 23: 643654. https://doi.org/10.1071/WF12137.

Poli, P., J. Pailleux, V. Ducrocq, P. Moll, F. Rabier, M. Mauprivez, S. Dufour, M. Grondin, F. Carvalho, J.-L. Issler, A. De Latour, and L. Ries. 2008. Weather report: meteorological applications of GNSS from space and on the ground. InsideGNSS 3 (8): 30-39.

Potter, B.E., J.A. Winkler, D.F. Wilhelm, R.P. Shadbolt, and X. Bian. 2008. Computing the low-elevation variant of the Haines index for fire weather forecasts. Weather and Forecasting 23 (1): 159-167. https://doi.org/10.1175/ 2007WAF2007025.1.

Río, M.E., and L. Achával. 1904. Geografía de la provincia de Córdoba, volume 1. Buenos Aires: Compañía Sud-Americana de Billetes de Banco [In Spanish.]. https://books.google.com.ar/books?id=XBwwDwAAQBAJ\&printsec=



Ropelewski, C.H., and S. Halpert. 1987. Global and regional scale precipitation patterns associated with the El Niño/Southern Oscillation. Monthly Weather Review 115: 1606-1626. https://doi.org/10.1175/1520-0493(1987)115<1606: GARSPP $>2.0 . C O ; 2$

Scott, J.H., and E.D. Reinhardt. 2001. Assessing crown fire potential by linking models of surface and crown fire behavior. Fort Collins: USDA Forest Service Research Paper RMRS-RP-29, Rocky Mountain Research Station. https://doi. org/10.2737/RMRS-RP-29.
Simpson, C.C., H.G. Pearce, A.P. Sturman, and P. Zawar-Reza. 2014. Behaviour of fire weather indices in the 2009-10 New Zealand wildland fire season. International Journal of Wildland Fire 23: 1147-1164. https://doi.org/10.1071/ WF12169.

Tatli, H., and M. Türkes. 2014. Climatological evaluation of Haines forest fire weather index over the Mediterranean basin. Meteorological Applications 21: 545-552. https://doi.org/10.1002/met.1367.

Winkler, J.A., B.E. Potter, D.F. Wilhelm, R.P. Shadbolt, K. Piromsopa, and X. Bian. 2007. Climatological and statistical characteristics of the Haines Index for North America. International Journal of Wildland Fire 16 (2): 139-152. https:// doi.org/10.1071/WF06086.

\section{Submit your manuscript to a SpringerOpen ${ }^{\odot}$ journal and benefit from:}

- Convenient online submission

- Rigorous peer review

- Open access: articles freely available online

- High visibility within the field

- Retaining the copyright to your article

Submit your next manuscript at $\boldsymbol{\nabla}$ springeropen.com 